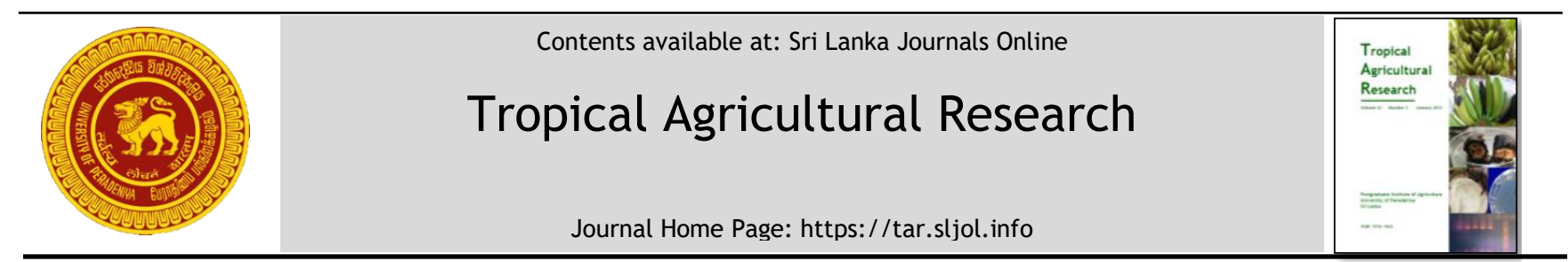

\title{
Water Availability, Crop Choices and Profitability of Farming: A Case Study of Mahakanumulla Tank Village
}

\author{
D. Dayananda ${ }^{1}$, J. Weerahewa ${ }^{2 *}$ and S. A. Weerasooriya ${ }^{2}$ \\ ${ }^{1}$ Postgraduate Institute of Agriculture, University of Peradeniya, Peradeniya, Sri Lanka. \\ ${ }^{2}$ Department of Agricultural Economics and Business Management, Faculty of Agriculture, University of Peradeniya, Sri \\ Lanka.
}

\section{ARTICLE INFO}

Article history:

Received: 18 July 2020

Revised version received: 23 October 2020

Accepted: 07 November 2020

Available online: 1 January 2021

Keywords:

Village tanks

Linear Programming

Crop mix

Rainfall

Profitability

\section{Citation:}

Dayananda, D., Weerahewa, J. and Weerasooriya S. A. (2021). Water Availability, Crop Choices, and Profitability of Farming: A Case Study of Mahakanumulla Tank Village. Tropical Agricultural Research, 32(1): 81-94.

DOI: http://doi.org/10.4038/tar.v32i1.8444

Dayananda, D.

https://orcid.org/0000-0003-0418-5658

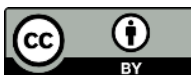

\section{ABSTRACT}

Village Tank Cascade Systems (VTCSs) were built in ancient Sri Lanka as self-reliant and climate-resilient agro-ecological systems. This study examined crop choices and profitability of farming under alternative rainfall regimes in a well-functioning tank village system in Mahakanumulla VTCS in Anuradhapura district. A Linear Programming (LP) model was developed to represent farming activities in the tank village for the 2018-19 Maha and 2019 Yala seasons using data gathered from secondary sources and a key informant survey. The baseline equilibrium was calibrated treating farmers as profit maximisers cultivating four types of land (uplands and lowlands in Maha and Yala seasons), two types of labour (hired and family), and twelve-monthly water constraints. The model was simulated under alternative rainfall regimes and technological interventions. The optimal crop mixes, farm profits, and shadow prices of resources associated with the baseline scenarios were compared with those of counterfactual scenarios. The results of the analysis indicated that the success of an intervention is determined by the rainfall regime. The analysis further showed that the introduction of a short-aged rice variety helps more in mitigating drought in a Maha season and the introduction of a traditional rice variety helps more in drought during Yala season. The positive effects of desiltation is quite large when a traditional rice variety is introduced in a Maha drought. Provision of seasonal weather forecasts, which will enable farmers to choose appropriate technological interventions, is recommended.

*Corresponding author : jeevikaw@pdn.ac.lk 


\section{INTRODUCTION}

Village Tank Cascade Systems (VTCSs) were built in ancient Sri Lanka as highly efficient systems for storing, conveying, and utilising rainwater (Bandara, 1985). Several studies have highlighted the degradation of VTCSs suggesting different restoration efforts (Bandara et al., 2010; IUCN, 2015; IUCN, 2016). To the best of the authors' knowledge, no attempt has been made so far to quantify the benefits of VTCS restoration using alternative restoration measures proposed in this study. Since limited resources are available for investment, it is important to ascertain potential benefits from such restoration strategies before they are implemented.

Optimisation models are widely used by agricultural economists for quantifying benefits under alternative scenarios. Several studies have been conducted in a Sri Lankan context to quantify the benefits of optimal land-use plans. For instance, Bogahawatte (1984) formulated a Linear Programming (LP) model to ascertain the croplivestock integrated farming systems that provide maximum profits to farm operators in three rainfed villages in the Moneragala district. Considering that farm producers possess multiple objectives, Weerahewa and Zuhair (1990) adopted a goal programming model (an extension to a LP model) to assess farmers' behaviour. Fernando et al. (2003) developed a multi-period LP to analyse the effects of farm-level resource constraints and government policies in coconut-based intercropping systems. Gamage (2017) also used a goal programming model to find an optimal land use allocation for five other field crops in the Anuradhapura district.

Linear Programming has been widely applied in other countries as well. Zenis et al. (2018) developed a LP model to determine optimal crop mixes under the model area of land, the amount of labour - comprised of family, wage, and temporary labour - and water limitations considered as constraints. Sofi et al. (2015) applied LP techniques to determine the optimum land allocation of five food crops, paying special attention to daily wages of labour and machine charges. Shreedhar et al. (2015) formulated a LP model to suggest the optimal cropping pattern giving the maximum net benefit at different levels of water availability in a reservoir in Karnataka, India. Nazer et al. (2011) developed a LP model to find the optimal irrigation water allocation in the West Bank of Palestine under three scenarios: (1) maintaining the existing cropping patterns; (2) maximising profit under water and land availability constraints; and, (3) maximising profit under water and land availability constraints.

The objective of this study was to examine the extent to which village tanks cushion the adverse effects of drought seasons in a typical VTCS. This study first develops a LP model to represent farming activities in the 2018-2019 Maha (wet season) and the 2019 Yala (dry season) for Mahakanumulla tank village. Then, it simulates the optimal crop choices that generate maximum profit from farming, considering various technological interventions proposed for the restoration of VTCSs. Simulations were carried out under alternative rainfall regimes treating partial desiltation and introduction of short-aged and high-value rice varieties as technological interventions.

\section{METHODOLOGY}

\section{Study Area}

Mahakanumulla tank village in the Anuradhapura district was selected as the study area. It is a part of Mahakanumulla VTCS, which consists of 27 village tanks distributed among nine Grama Niladhari Divisions covering 1,085 ha of land. Mahakanumulla VTCS is administered by the Thirappane, Kekirawa and Ipalogama Divisional Secretariats, and Mahakanumulla tank village fall under Thirappane Divisional Secretariat. According to Divisional Secretariat data, Mahakanumulla Grama Niladhari division counts 532 persons and 112 households. The irrigation infrastructure in the village is being maintained by the Department of Agrarian Service in Thirappane.

Mahakanumulla village tank is the largest village tank of the Mahakanumulla VTCS and is considered as one of the village tanks that is being well managed by the Agrarian Service Centres and farmer organisations. The village consists of 97.22 ha of lowland and 18.21 ha of upland. Both Yala and Maha seasons are being cultivated using rainfall, tank water, and groundwater resources.

\section{Structure of the Linear Programming Model}

As indicated earlier, a LP model can determine optimal levels of decision variables under a set of constraints to achieve a specific objective. The structure of a LP consists of: (1) an objective function to be maximised or minimised; (2) activities or decision variables, which are the ways to carry out the objective; (3) objective function coefficients, which translate an overall numeric value to the objective through interaction with the 
values of the activities; and, (4) a set of constraints that model the restrictions so that the decisionmaker must operate within those limits. The general form of the linear programming model is given below.

Objective function:

$$
\operatorname{Max} Z=\sum_{j=1}^{n} \mathrm{C}_{\mathrm{j}} \mathrm{x}_{\mathrm{j}}
$$

subject to,

$$
\sum_{i=1}^{m} \mathrm{a}_{\mathrm{ij}} \mathrm{x}_{\mathrm{j}} \leq \mathrm{b}_{\mathrm{i}} \forall i
$$

$x_{j} \geq 0 \forall j$

The above model presents $Z$ as profit; $C_{j}$ as coefficient of the $j^{\text {th }}$ decision variable; $a_{i j}$ as the $j^{\text {th }}$ coefficient of the $i^{\text {th }}$ constraint; $X_{j}$ as the $j^{\text {th }}$ decision variables; and, $b_{i}$ as the $i^{\text {th }}$ resource limit.

\section{Data and Calibration}

The above model was extended to capture key characteristics of the Mahakanumulla tank village in the following manner. First, the key constraints of the village tank system were identified based on data gathered from a key informant survey and secondary sources. The key informants were the Agriculture Inspector for Mahakanumulla, the President of the Mahakanumulla farmers' organisation, and the person responsible for water operations for a season. Water, land, and labour were the major constraints of the Mahakanumulla village tank system (Bandara, 2004; Withanachchi et al., 2014). Altogether, 18 different constraints were identified, i.e., 2 labour constraints, 12 monthly water constraints, and 4 land constraints to represent lowlands and highlands in the Yala and Maha seasons. Accordingly, in the baseline equilibrium of the above model $m$ was treated as 18 ( $i$ ranged from 1 to 18 ).

The farmers, together with relevant authorities, manage Mahakanumulla tank in order to obtain irrigation water for crop cultivation. Data related to labour usage, fertilizer usage, average yields, and profits from crop cultivation were extracted from the costs of cultivation bulletins issued by the Department of Agriculture and adjusted to the setting in Mahakanumulla. Rice, maize and vegetables cultivated in Yala and Maha seasons were the decision variables considered in the baseline equilibrium. Table 1 provides data on the labour usage and net profits of rice, maize, and vegetables for the 2018 Yala and 2017-2018 Maha seasons. These values and the discussions with the key-informants were used to construct the labour use coefficients $\left(a_{i j}\right)$ and to construct the coefficients in the profit equation $\left(c_{j}\right)$ in the above model. Accordingly, the number of decision variables $(n)$ in the above model was $6(j$ ranged from 1 to 6 ). The detailed LP model is shown in Supplementary material-Table S1.

Coefficients of monthly water constraints were calculated using the Crop Water Requirement (CWR) of plants, which are dependent on the type of plant and evapotranspiration, at different growth stages. Table 2 illustrates the CWR of the crops that can be potentially cultivated in the study area. The CWRs were used to construct $a_{i j}$ coefficients relevant to water constraints.

Table 1: Labour usage and profitability of rainfed rice in Yala and Maha seasons in Anuradhapura

\begin{tabular}{|c|c|c|c|c|c|}
\hline \multirow{2}{*}{ Crop } & \multirow{2}{*}{ Year } & \multicolumn{3}{|c|}{ Labour (Man-days/ha) } & \multirow{2}{*}{$\begin{array}{l}\text { Net profit } \\
\text { (LKR/ha) }\end{array}$} \\
\hline & & Family & Hired & Total & \\
\hline \multirow{2}{*}{ Rice } & 2018 Yala & 37 & 7 & 44 & 67,908 \\
\hline & 2017-18 Maha & 12 & 12 & 25 & 19,583 \\
\hline \multirow{2}{*}{ Maize } & 2018 Yala & 74 & 35 & 109 & 100,621 \\
\hline & 2017-18 Maha & 54 & 57 & 111 & 49,598 \\
\hline \multirow{2}{*}{ Vegetables } & 2018 Yala & 126 & 84 & 217 & 316,288 \\
\hline & 2017-18 Maha & 168 & 114 & 415 & 295,386 \\
\hline
\end{tabular}
district

Source: Department of Agriculture, 2017-18 
Table 2: Crop water requirement by the growth stage of the crop (ha-meter) ${ }^{*}$

\begin{tabular}{|c|c|c|c|c|c|}
\hline Crop type & $\begin{array}{l}\text { Initial } \\
\text { stage }\end{array}$ & $\begin{array}{l}\text { Development } \\
\text { stage }\end{array}$ & $\begin{array}{l}\text { Mid- } \\
\text { stage }\end{array}$ & $\begin{array}{l}\text { Late- } \\
\text { stage }\end{array}$ & Total/Season \\
\hline $\begin{array}{l}\text { Rice ( } 4 \text { months variety and } \\
\text { traditional variety for both } \\
\text { seasons) }\end{array}$ & 0.056 & 0.113 & 0.207 & 0.107 & 0.485 \\
\hline $\begin{array}{l}\text { Rice ( } 3 \text { months variety- } \\
\text { Yala) }\end{array}$ & 0.138 & 0.115 & & 0.115 & 0.368 \\
\hline $\begin{array}{l}\text { Rice ( } 3 \text { months variety- } \\
\text { Maha) }\end{array}$ & 0.059 & 0.060 & & 0.106 & 0.226 \\
\hline Maize (both seasons) & 0.023 & 0.078 & 0.150 & 0.051 & 0.302 \\
\hline Vegetables (both seasons) & 0.016 & 0.036 & 0.078 & 0.032 & 0.164 \\
\hline
\end{tabular}

Source: FAO, 2020; Kanthilanka, 2020

Rainfall, groundwater, and tank-stored water are the three main water sources for agriculture in this village. Groundwater availability and rainfall efficiency were calculated using the hydrological accounting figures described below. The total irrigation water availability in the village tank was calculated considering extents cultivated in a typical year and CWRs and tank water availability was considered as the residual after subtracting water from rainfall and groundwater. According to the hydrological studies, $60 \%$ of rainfall is available for crop production, while $9 \%$ of rainfall percolates to recharge the groundwater aquifer (Itakura, 1995; Gunawardena and Dayawansa, 2020; Rajendran et al., 2020). According to the key informants, in a typical Maha season, farmers cultivated the total extent of lowland. In a typical Yala season, only one-third of the lowland was cultivated. The above extents were used in computing water usage in the two seasons covered and used to construct the water resource limits $\left(b_{i}\right)$ of the baseline equilibrium of the above model. A similar approach was adopted to construct limits of the other resources, namely land and labour. The detailed LP model set up for the baseline equilibrium is given in Supplementary materialTable S1.

\section{Development of Drought Scenarios}

Rainfall data at the Mahailluppallama weather station during 2009-2019 were obtained from the
District Survey Office in Anuradhapura and were used to generate drought seasons. Figures 1 and 2 present monthly rainfall distribution during the Maha and Yala seasons during 2009-2019.

Of the Maha seasons, 2016-17 and 2012-13 recorded the lowest and highest rainfall respectively. Therefore, the 2016-17 Maha rainfall was considered as the Maha drought period. Of the Yala seasons, the 2013 and 2018 seasons received the lowest and highest rainfall, respectively, and the 2013 Yala rainfall was considered as the Yala drought period. The baseline scenario was developed considering rainfall received during the 2018-19 Maha and 2019 Yala which depict the rainfall in a good rainy year. Using the rainfall data presented in Figures 1 and 2, direct rainfall and underground water capacities were calculated. Moreover, considering the tank water capacities in each month, direct rainfall and groundwater discharge of total irrigation water availability were calculated.

Table 3 presents the available water for irrigation with and without desiltation of the tank. The baseline resembles 2018/2019 Maha and 2019 Yala and they are considered as seasons with good rains.

\footnotetext{
* The crop water requirement primarily depends on temperature. Therefore, reference evapotranspiration during Maha and Yala seasons are different and Yala reflects comparatively high requirement.
} 


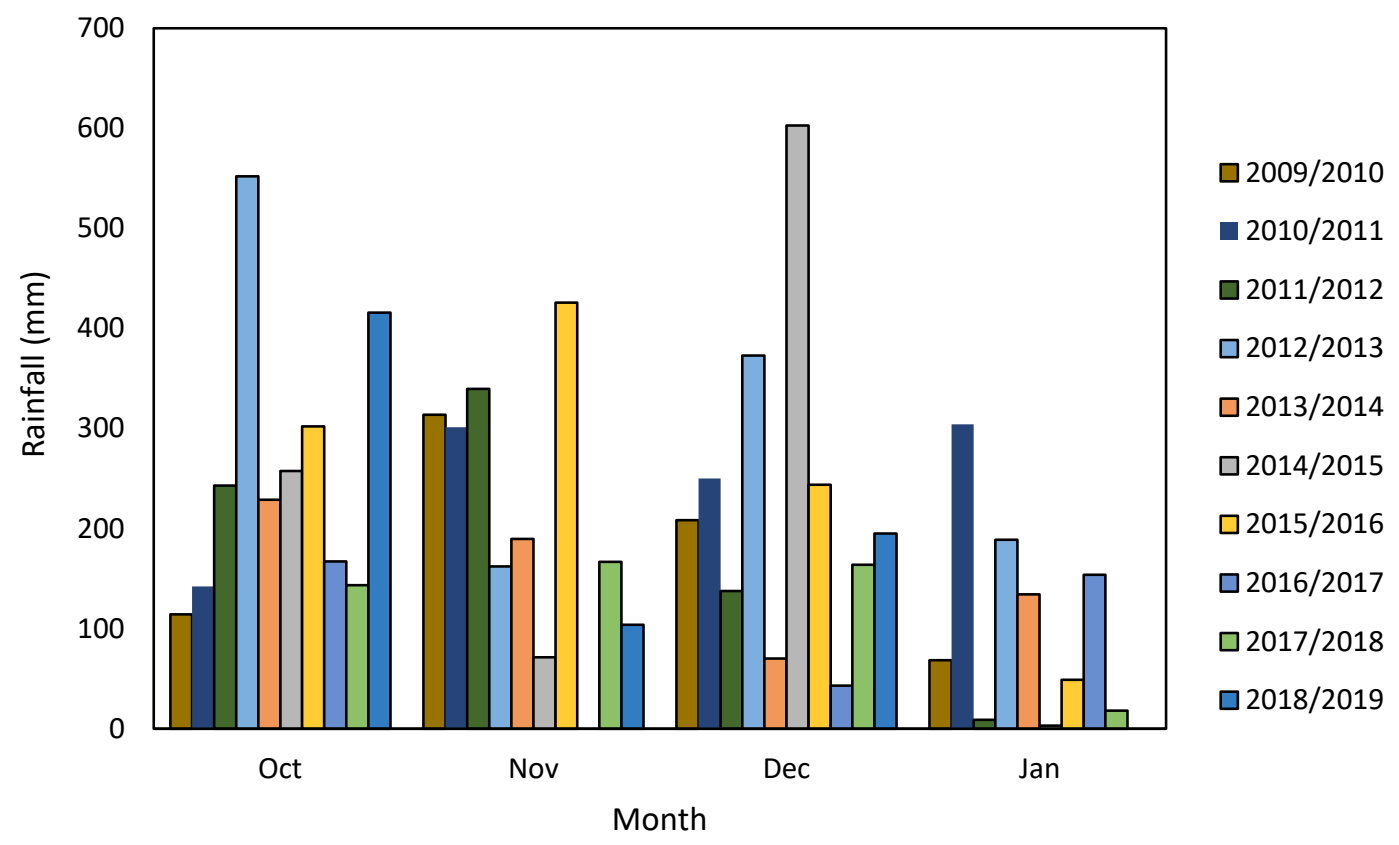

Figure 1: Rainfall distribution in the Maha season (2009/10 to 2018/19)

Source: District Survey Office, Anuradhapura

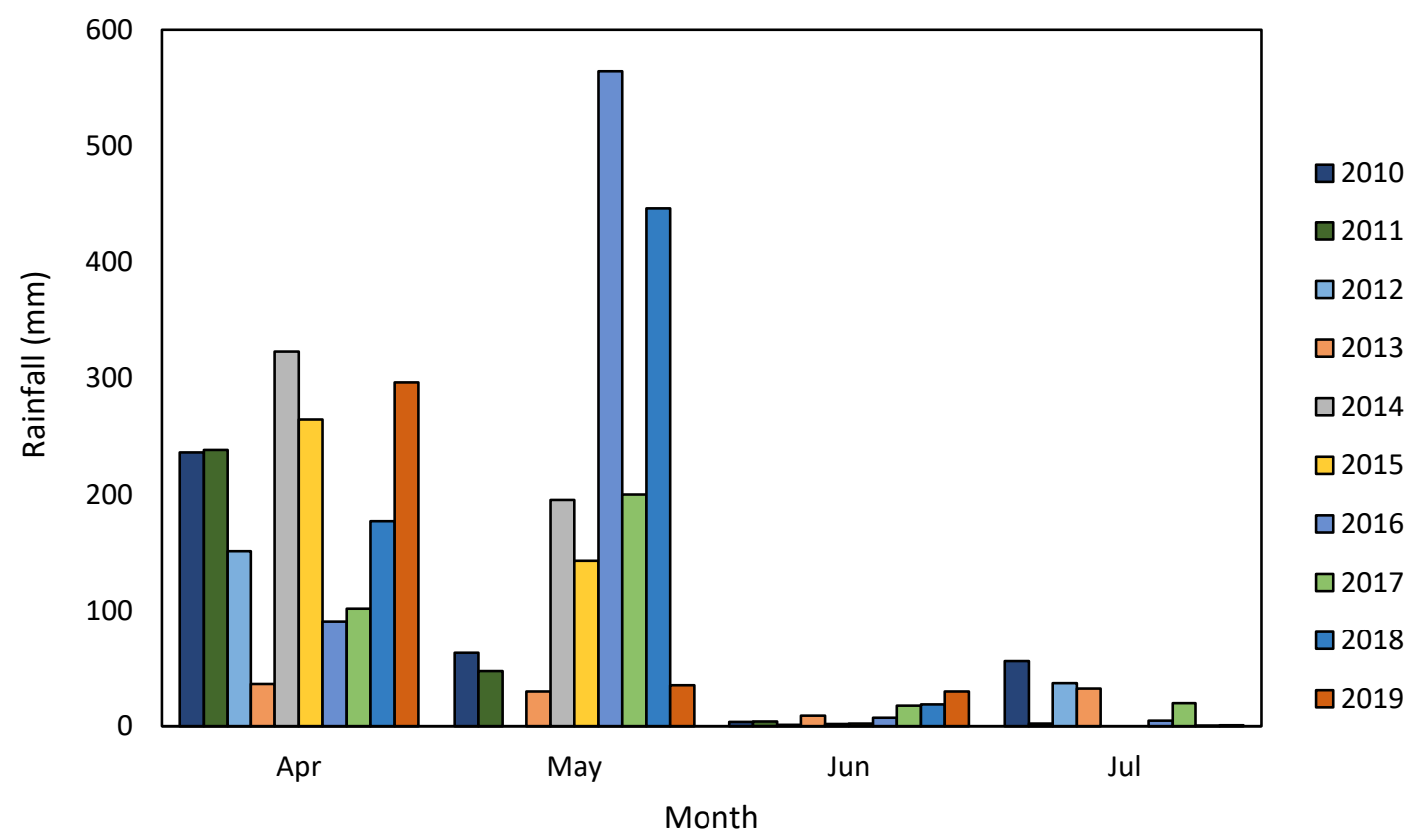

Figure 2: Rainfall distribution in the Yala season (2009 to 2019)

Source: District Survey Office, Anuradhapura 
Table 3: Irrigation water availability of the different rainwater availability scenarios (ha-meter)

\begin{tabular}{|c|c|c|c|c|c|c|c|c|}
\hline \multirow[b]{2}{*}{ Month } & \multicolumn{2}{|c|}{ Good year } & \multicolumn{2}{|c|}{ Yala drought } & \multicolumn{2}{|c|}{ Maha drought } & \multicolumn{2}{|c|}{ Year-round drought } \\
\hline & Baseline & Desilted tank & Baseline & $\begin{array}{c}\text { Desilted tank/ } \\
\text { Yala drought }\end{array}$ & Baseline & $\begin{array}{l}\text { Desilted tank/ } \\
\text { Maha drought }\end{array}$ & Baseline & $\begin{array}{c}\text { Desilted tank/ } \\
\text { Year-round } \\
\text { drought }\end{array}$ \\
\hline October & 13.52 & 13.52 & 13.52 & 13.52 & 0.00 & 0.00 & 0.00 & 0.00 \\
\hline November & 27.79 & 39.90 & 27.79 & 39.90 & 16.39 & 28.50 & 16.39 & 28.50 \\
\hline December & 50.82 & 66.19 & 50.82 & 66.19 & 35.24 & 50.60 & 35.24 & 50.60 \\
\hline January & 26.16 & 40.71 & 26.16 & 40.71 & 26.16 & 40.71 & 26.16 & 40.71 \\
\hline February & 0.00 & 8.01 & 0.00 & 8.01 & 0.00 & 8.01 & 0.00 & 8.01 \\
\hline March & 0.00 & 8.01 & 0.00 & 8.01 & 0.00 & 8.01 & 0.00 & 8.01 \\
\hline April & 5.51 & 11.56 & 0.00 & 0.00 & 5.51 & 11.56 & 0.00 & 0.00 \\
\hline May & 11.33 & 21.77 & 9.74 & 20.18 & 11.33 & 21.77 & 9.74 & 20.08 \\
\hline June & 20.74 & 33.60 & 19.49 & 32.35 & 20.74 & 33.60 & 19.49 & 32.35 \\
\hline July & 10.66 & 21.33 & 10.63 & 21.30 & 10.66 & 21.33 & 10.63 & 21.30 \\
\hline August & 0.00 & 8.01 & 0.00 & 8.01 & 0.00 & 8.01 & 0.00 & 8.01 \\
\hline September & 0.00 & 8.01 & 0.00 & 8.01 & 0.00 & 8.01 & 0.00 & 8.01 \\
\hline
\end{tabular}




\section{Development of Intervention Scenarios}

The intervention scenarios closely mimic various technologies introduced through development projects implemented to restore and rehabilitate the VTCSs (Supplementary material-Box S1). These interventions can be classified as short-term, medium-term, and long-term. Short-term interventions are shramadana campaigns; preparation of socio-economic and ecological databases; and, awareness programmes. Mediumterm interventions include partial desilting; bund repairs; and structural improvements of minor irrigation systems. Long-term interventions include the development and introduction of drought-tolerant varieties as well as making seeds, other inputs, and marketing channels available (IUCN, 2015; IUCN, 2016). In most of the projects, desilting of tanks is undertaken as a compulsory activity. The examples include "Wew Gam Pubuduwa" and "Wari Saubhagya". Accordingly, desiltation was considered as one of the interventions. It was obtained by increasing the water holding capacity of the village tank by $25 \%$ (Table 3). The introduction of short-aged variety (3-month duration) was chosen as the second intervention. As the third intervention, the introduction of a traditional variety (a high value crop) to the system was chosen. The latter was coupled with a provision of organic matter required for the cultivation of the traditional variety.

\section{Development of Simulation Scenarios}

Each climate scenario was simulated along with the three hypothetical technological intervention scenarios described above. The detailed scenarios considered for model simulations are presented in Table 4.

The CWRs of short-aged variety and traditional variety are shown in Table 2 and their labour requirements were treated as same as the fourmonth variety used in the baseline equilibrium. Data related to input usage other than CWRs, yields, prices and profits of the short-aged variety was considered as same as the four-month variety and that for the traditional variety was gathered from Dharmasena (2010). Even though the yields of traditional variety are lower (approximately $3,367 \mathrm{~kg} / \mathrm{ha}$ ) compared to high yielding varieties (approximately 4,736 kg/ha), higher profits can be obtained if a marketing channel can be secured. In this study, profits from traditional rice were considered as 91,427 LKR/ha including the cost of applying organic matter and bio-pesticides. The organic manure requirement for cultivation of traditional rice was considered as $28,095 \mathrm{~kg} / \mathrm{ha}$ (Sirisena et al., 2016). The key differences between the five enterprises are summarized in Table 5.

It is noteworthy to mention that in the simulations with short-aged varieties and traditional rice, the LP tableaus were extended to include them as new decision variables. Accordingly, the number of decision variables in simulations involving shortaged varieties and traditional varieties increased to 10 as each was accommodated in both seasons; Yala and Maha.

Table 4: Climate and intervention scenarios

\begin{tabular}{lll}
\hline & Scenario & \multicolumn{1}{c}{ Description } \\
\hline Climate & Baseline & 2018-19 Maha and 2019 Yala \\
& Yala drought & 2018-19 Maha and 2013 Yala \\
& Maha drought & 2012-13 Maha and 2019 Yala \\
& Maha and Yala drought & 2012-13 Maha and 2013 Yala \\
\hline Intervention & Desiltation & Partial desiltation to improve tank capacity by 25\% \\
Scenarios & Short-aged rice & Introduce a short-aged rice variety \\
& Short-aged rice + & Introduce a short-aged rice variety after tank desiltation \\
& desiltation & Introduce four-month aged traditional rice variety \\
& Traditional rice & Introduce traditional rice variety after tank desiltation \\
& Traditional rice + & \\
& desiltation &
\end{tabular}


Table 5: Profitability, labour requirement and organic matter requirement of different crop enterprises per season.

\begin{tabular}{lcccccc}
\hline \multicolumn{1}{c}{ Variable } & Unit & $\begin{array}{c}\text { Rice } \\
\text { (4- } \\
\text { months) }\end{array}$ & $\begin{array}{c}\text { Rice } \\
\text { (3-months) }\end{array}$ & $\begin{array}{c}\text { Traditional } \\
\text { rice }\end{array}$ & Maize & Vegetables \\
\hline Profit & LKR/ha & 70,424 & 70,424 & 91,427 & 93,898 & 296,520 \\
\hline Family labour & $\begin{array}{c}\text { Man } \\
\text { days/ha }\end{array}$ & 32 & 32 & 32 & 101 & 126 \\
\hline Hired labour & $\begin{array}{c}\text { Man } \\
\text { days/ha }\end{array}$ & 15 & 15 & 15 & 15 & 77 \\
\hline Organic matter & $\mathrm{kg} / \mathrm{ha}$ & - & - & 28,095 & - & - \\
\hline
\end{tabular}

\section{RESULTS AND DISCUSSION}

The optimal crop plans, profitability of farming, and shadow prices under the baseline and simulation scenarios were the key results of the analysis. The results clearly indicated that the availability of water drives the choice of crop plans and the profitability of farming. Tables 6 to 9 present optimal crop plans of farming under a good year, Yala drought, Maha drought, and a yearround drought together with counterfactual scenarios respectively. Profits generated under different scenarios are presented in Figure 3. The shadow prices of the key resources are shown in Supplementary material -Tables S2 and S3.

As indicated earlier, the baseline equilibrium which reflected the 2018-19 Maha season and the 2019 Yala seasons were good rainy seasons. Lowlands are utilised fully in the Maha season with annual profits of LKR $10,618,736$. As shown in Table 6 , the extents cultivated by maize and vegetables were less than 2.02 ha each in both seasons. Although net profit from the cultivation of rice was comparatively low, rice remained the dominant crop in both seasons as the labour requirements were higher for upland crops. Supplementary material -Table S3 shows that both family and hired labour constraints in both Yala and Maha seasons were binding. If the tank was partially desilted, a relatively larger extent would have been cultivated in Yala increasing profits by $1.90 \%$ from the baseline (Figure 3). Marques et al. (2005) reported similar findings where increased reliability of water supply raised the probability of higher economic returns for crops. However, the introduction of a short-aged rice variety to the system would not significantly change the crop mix as the water was available in sufficient quantities to cultivate a four-month rice variety. The inclusion of a traditional variety to the system, after desilting the tank, would enable farmers to earn some sizable income from cultivation. The increase in profit with the introduction of a traditional variety was $27 \%$ from the baseline, and this increased to $32 \%$ if the introduction was accompanied by partial desiltation (Figure 3).

Table 7 presents a situation of drought in the Yala season. The equilibrium in a good rainy year was simulated with lower water availability in the Yala season to obtain the 'baseline' equilibrium under this scenario. Consequently, profits associated with this situation were lower, compared to a situation with good rains depicted in Table 6, as Yala would not be cultivated due to lower water availability. With partial desiltation, profitability could be slightly improved as Maha season cultivation could be expanded. If a short-aged variety was introduced to the system, it enabled cultivation in Yala and it could be further expanded with partial desiltation. This suggests that the introduction of the short-aged rice variety can mitigate the challenges arising from lower water availability which was associated with delays in the onset and short duration of the seasons in this scenario. The introduction of a traditional variety will not help in cultivation in the Yala season (because traditional variety requires more water compared to shortaged varieties), but it would help to increase the annual profit by shifting the rice cultivation to the traditional variety in Maha season. The percentage change in profits from the baseline in this scenario due to the introduction of a traditional rice variety was $19 \%$ and it could be improved to $20 \%$ if it accompanied with partial desiltation. 

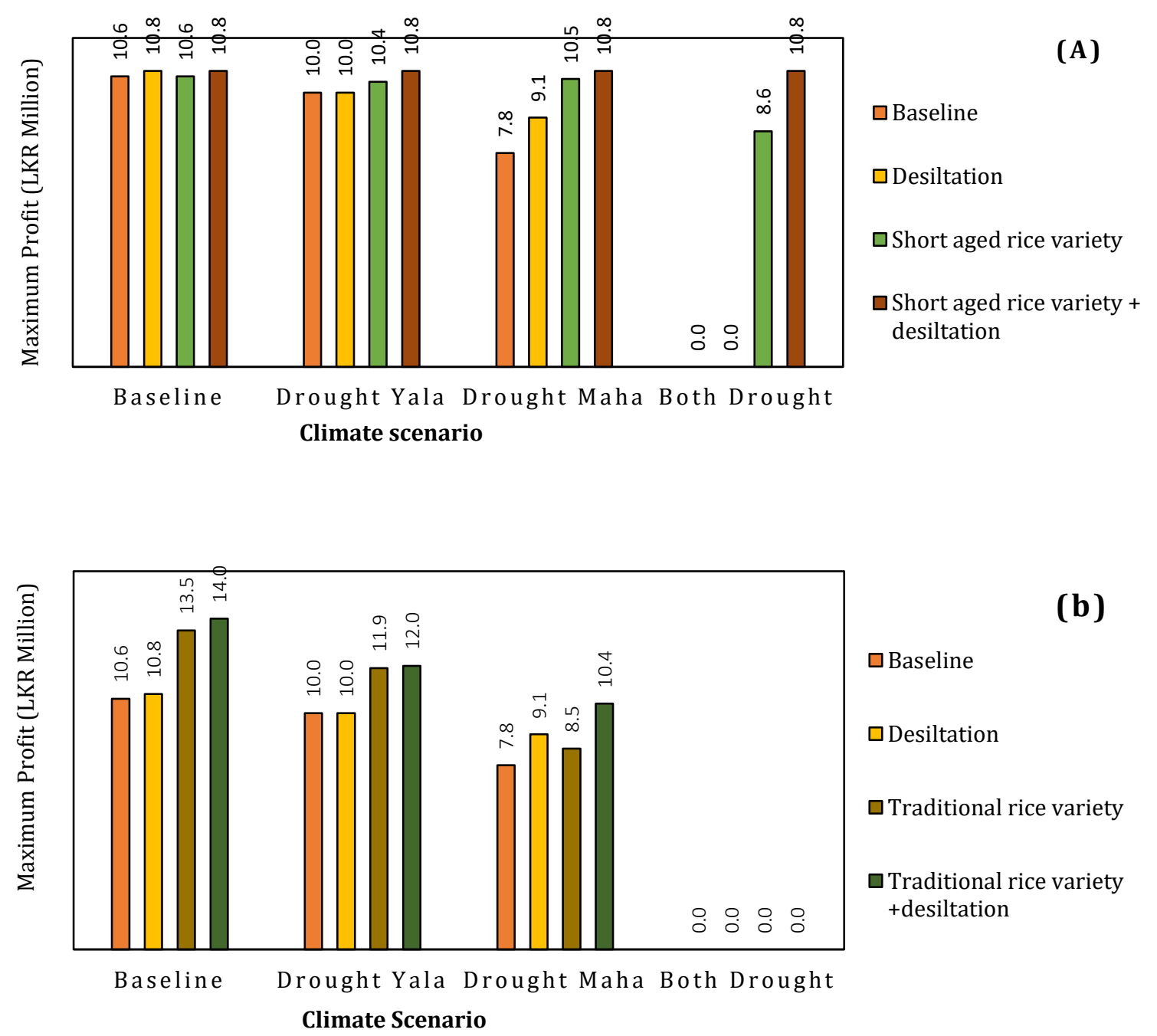

Figure 3: Maximum profits under different climate and intervention scenarios. (a) With introduction of short-aged rice varieties, and (b) with introduction of a traditional rice variety.

Next, the equilibrium in a good year was simulated with low water availability in Maha. According to the results of Table 8, a Maha drought season has a large effect on the profitability of the system and it clearly shows the Maha rainfall has more detrimental effects on year-round cultivation pattern and profitability compared to those of a Yala drought. Partial desiltation helped improving profitability by $18 \%$ and an introduction of shortduration rice improved it up to $36 \%$ from the baseline of this scenario. The marginal effects on profitability owing to desiltation after the introduction of a short-aged variety was small (increase from $36 \%$ to $39 \%$ ). Meanwhile, the system could generate higher profits, compared to the baseline, by cultivating traditional varieties under desilted tanks in the Yala season. These results clearly showed the benefits of desiltation are quite high in the presence of drought in the Maha season (Figure 3).

Table 9 illustrates a year-round drought scenario. In an extreme drought no crops could be cultivated even if tank capacity was improved by $25 \%$ through partial desiltation or a traditional variety was introduced. However, if farmers were provided with a short-aged variety, some profits could be recovered. The provision of additional tank water, through partial desiltation, can further increase profitability if a short-aged variety is cultivated (Figure 3). 
Table 6: Optimal crop mixes under baseline and counterfactual scenario (Extent in ha)

\begin{tabular}{|c|c|c|c|c|c|c|c|}
\hline Season & Crop & Baseline & Desiltation & $\begin{array}{l}\text { Short- } \\
\text { aged } \\
\text { variety }\end{array}$ & $\begin{array}{c}\text { Short-aged } \\
\text { variety }+ \\
\text { desiltation }\end{array}$ & $\begin{array}{l}\text { Traditional } \\
\text { variety }\end{array}$ & $\begin{array}{c}\text { Traditional } \\
\text { variety }+ \\
\text { Desiltation }\end{array}$ \\
\hline \multirow[t]{5}{*}{ Maha } & $\begin{array}{l}\text { Rice (4- } \\
\text { months) }\end{array}$ & 97.23 & 97.33 & 97.23 & 97.23 & & \\
\hline & $\begin{array}{l}\text { Rice (3- } \\
\text { months) }\end{array}$ & & & 0.02 & & & \\
\hline & $\begin{array}{l}\text { Traditional } \\
\text { rice }\end{array}$ & & & & & 97.23 & 97.23 \\
\hline & Maize & 2.00 & & 2.00 & & 2.00 & \\
\hline & Vegetables & 1.53 & & 1.51 & & 1.53 & \\
\hline \multirow[t]{5}{*}{ Yala } & $\begin{array}{l}\text { Rice (4- } \\
\text { months) }\end{array}$ & 39.54 & 55.28 & 39.53 & 55.28 & & \\
\hline & $\begin{array}{l}\text { Rice (3- } \\
\text { months) }\end{array}$ & & & & & & \\
\hline & $\begin{array}{l}\text { Traditional } \\
\text { rice }\end{array}$ & & & & & 39.54 & 55.28 \\
\hline & Maize & 0.83 & 0.87 & 0 & 0.87 & 0.83 & 0.87 \\
\hline & Vegetables & 0.91 & & 0.91 & & 0.91 & \\
\hline
\end{tabular}

Table 7: Optimal crop mixes under a Yala drought scenario (Extent in ha)

\begin{tabular}{|c|c|c|c|c|c|c|c|}
\hline Season & Crop & Baseline & Desiltation & $\begin{array}{l}\text { Short- } \\
\text { aged } \\
\text { variety }\end{array}$ & $\begin{array}{c}\text { Short-aged } \\
\text { variety + } \\
\text { desiltation }\end{array}$ & $\begin{array}{l}\text { Traditional } \\
\text { variety }\end{array}$ & $\begin{array}{c}\text { Traditional } \\
\text { variety + } \\
\text { desiltation }\end{array}$ \\
\hline \multirow[t]{5}{*}{ Maha } & $\begin{array}{l}\text { Rice (4- } \\
\text { months) }\end{array}$ & 89.47 & 91.90 & 93.92 & 97.23 & & \\
\hline & $\begin{array}{l}\text { Rice (3- } \\
\text { months) }\end{array}$ & & & 1.15 & & & \\
\hline & $\begin{array}{l}\text { Traditional } \\
\text { rice }\end{array}$ & & & & & 89.47 & 91.90 \\
\hline & Maize & 8.42 & 8.44 & 4.56 & 0.87 & 8.42 & 8.44 \\
\hline & Vegetables & 9.79 & 9.36 & 4.56 & & 9.79 & 9.37 \\
\hline \multirow[t]{5}{*}{ Yala } & $\begin{array}{l}\text { Rice (4- } \\
\text { months) }\end{array}$ & & & & & & \\
\hline & $\begin{array}{l}\text { Rice (3- } \\
\text { months) }\end{array}$ & & & 27.89 & 55.28 & & \\
\hline & $\begin{array}{l}\text { Traditional } \\
\text { rice }\end{array}$ & & & & & & \\
\hline & Maize & & & & & & \\
\hline & Vegetables & & & & & & \\
\hline
\end{tabular}


Table 8: Optimal crop mixes under a Maha drought scenario (Extent in ha)

\begin{tabular}{|c|c|c|c|c|c|c|c|}
\hline Season & Crop & Baseline & Desiltation & $\begin{array}{c}\text { Short- } \\
\text { aged } \\
\text { variety }\end{array}$ & $\begin{array}{c}\text { Short- } \\
\text { aged } \\
\text { variety }+ \\
\text { desiltation }\end{array}$ & $\begin{array}{c}\text { Traditional } \\
\text { variety }\end{array}$ & $\begin{array}{c}\text { Traditional } \\
\text { variety + } \\
\text { desiltation }\end{array}$ \\
\hline \multirow[t]{5}{*}{ Maha } & $\begin{array}{l}\text { Rice (4- } \\
\text { month) }\end{array}$ & & & & & & \\
\hline & $\begin{array}{l}\text { Rice (3- } \\
\text { months) }\end{array}$ & & & 93.76 & 97.23 & & \\
\hline & $\begin{array}{l}\text { Traditional } \\
\text { rice }\end{array}$ & & & & & & \\
\hline & Maize & & & & & & \\
\hline & Vegetables & & & & & & \\
\hline \multirow[t]{5}{*}{ Yala } & $\begin{array}{l}\text { Rice (4- } \\
\text { month) }\end{array}$ & 33.67 & 58.19 & 36.41 & 55.28 & & \\
\hline & $\begin{array}{l}\text { Rice (3- } \\
\text { months) }\end{array}$ & & & 0.35 & & & \\
\hline & $\begin{array}{l}\text { Traditional } \\
\text { rice }\end{array}$ & & & & & 33.67 & 58.19 \\
\hline & Maize & & 1.72 & 3.62 & 0.87 & & 1.72 \\
\hline & Vegetable & 18.21 & 16.49 & 3.40 & & 18.21 & 16.49 \\
\hline
\end{tabular}

Table 9: Optimal crop mixes under a drought during both seasons scenario (Extent in ha)

\begin{tabular}{|c|c|c|c|c|c|c|c|}
\hline Season & Crop & Baseline & Desiltation & $\begin{array}{l}\text { Short- } \\
\text { aged } \\
\text { variety }\end{array}$ & $\begin{array}{c}\text { Short- } \\
\text { aged } \\
\text { variety }+ \\
\text { desiltation }\end{array}$ & $\begin{array}{l}\text { Traditional } \\
\text { variety }\end{array}$ & $\begin{array}{c}\text { Traditional } \\
\text { variety + } \\
\text { desiltation }\end{array}$ \\
\hline \multirow[t]{5}{*}{ Maha } & $\begin{array}{l}\text { Rice (4- } \\
\text { month) }\end{array}$ & & & & & & \\
\hline & $\begin{array}{l}\text { Rice (3- } \\
\text { months) }\end{array}$ & & & 93.76 & 97.23 & & \\
\hline & $\begin{array}{l}\text { Traditional } \\
\text { rice }\end{array}$ & & & & & & \\
\hline & Maize & & & & & & \\
\hline & Vegetables & & & & & & \\
\hline \multirow[t]{5}{*}{ Yala } & $\begin{array}{l}\text { Rice (4- } \\
\text { months) }\end{array}$ & & & & & & \\
\hline & $\begin{array}{l}\text { Rice (3- } \\
\text { months) }\end{array}$ & & & 27.89 & 56.15 & & \\
\hline & $\begin{array}{l}\text { Traditional } \\
\text { rice }\end{array}$ & & & & & & \\
\hline & Maize & & & & & & \\
\hline & Vegetables & & & & & & \\
\hline
\end{tabular}


A comparison of profits under alternative scenarios illustrated that annual profits are more or less the same with the introduction of shortaged variety after desiltation under alternative drought scenarios. Further, profits earned in a good year could be matched with the introduction of short-aged rice variety under drought in Yala or Maha. Profits with traditional variety however were always higher than those under other intervention scenarios except under a year-round drought. However, traditional rice cultivation was only feasible if organic manure was available and market access was guaranteed. Monaco et al. (2016) used a linear optimization model to explore the optimal allocation of land for rice subject to three different irrigation strategies stemming from limited water availability. Their findings bolster and demonstrate the key role of prioritizing one objective over the other while introducing varieties more suitable for limited water availability. Similarly, Singh (2016) and Daghighi et al. (2017) highlighted the importance of using the proper crop choice to counter scarce water availability.

The shadow prices of the water constraints of the model under alternative scenarios are presented in Supplementary material- Table S2. Water constraints during October and April (the first months of the Maha and Yala seasons, respectively) were binding in most of the scenarios analysed. Family labour and hired labour under most of the scenarios examined were binding as shown in Supplementary material -Table S3. The availability of lowlands and organic matter did not constrain the optimal crop plans examined under alternative scenarios.

The findings of this study are in precedent with the literature. Jain et al. (2019) used a LP approach to develop an optimal crop plan. Their study found that restricted water-use played a significant role in the choice of crops in Punjab, India. They found that increased water availability increased the area under paddy and subsequently, the revenue. Singh (2017) used a LP model for the optimal allocation of available good quality water and land resources to maximize the farm revenue of a canal command area. The author found that optimal land and water

\section{REFERENCES}

Bandara, C.M. (1985). Catchment ecosystems and village tank cascades in the dry zone of Sri Lanka: A time-tested system of land and water resource management. Strategies for river basin management. Springer. 99-113.

Bandara, C.M. (2004). Small tank cascade systems: their relevance for minor irrigation resource allocation can influence the farm revenue and LP models can be used as a reliable tool to solve irrigation-induced environmental problems of agricultural systems.

\section{CONCLUSIONS AND IMPLICATIONS}

The results of the analysis clearly showed that irrigation water and labour are the key determinants of the optimal crop mix and hence the profitability of farming in Mahakanumulla village. The availability of water at the beginning of the season is the most binding. Accordingly, improvement in tank capacity through partial desiltation helps to restore profitability. If a shortaged variety of rice is available, farmers can start late cultivation, bypassing the month with water constraints and avoiding the loss in profits. Department of Agriculture breeding programmes orientation towards this direction would hence benefit dry zone farmers. The introduction of a traditional variety of rice is the most financially successful intervention. Its sustainability however depends on the availability of market channels and organic matters. Connecting to high-value market chains is one of the most sustainable long-term strategies to increase profitability. Better water management practices, such as partial desilting, is the only feasible option with a year-round drought. However, with seasonal droughts, its effects on profitability are only marginal indicating that the returns on technological interventions depend on the climate scenario. The provision of seasonal forecasts on rains before the commencement of the season will certainly help farmers to choose the intervention that helps them in reaping maximum profits.

\section{ACKNOWLEDGMENT}

This work was financially supported by the project grant of AHEAD/RA3/DOR/STEM/ PDN/No 52 of the program titled Accelerating Higher Education Expansion and Development (AHEAD) administered by the Ministry of Higher Education, Sri Lanka.

rehabilitation. Small Tank Settlements in Sri Lanka,43-47.

Bandara, C. M., Yatigammana, S. and Paranavithana, G. (2010). Scientific validation of some traditional land and water management practices under village tank cascade systems. Economic Review. 36. 
Bogahawatte, C. (1984). Evaluating crop-livestockbased farming systems: A village level study in the dry zone rainfed district of Sri Lanka. Agricultural Systems. 14(4), 199-212.

Daghighi, A., Nahvi, A. and Kim, U. (2017). Optimal cultivation pattern to increase revenue and reduce water use: Application of linear programming to Arjan plain in Fars province. Agriculture, 7(9), 73.

Gunawardena, D.L.K. and Dayawansa, N.D.K. (2020). Assessment of Water Availability for Agriculture and Other Uses-Development of Indices for Deduru Oya River Basin in Sri Lanka. In: Water, Flood Management and Water Security Under a Changing Climate. Springer, Cham. 187-200.

Dharmasena, P.B. (2010). Assessment of Traditional Rice Farming: A Case Study from Moneragala District of Sri Lanka. Badulla: Future in Our Hand Development Fund.

Fernando, N., Edwards, I.E., Thomson, K. J. and Daw, M. (2003). Effect of farm-level constraints, existing and prospective policies on expansion of coconut-based intercropping in Sri Lanka (No. 1027-2016-82126).

Gamage, A. (2017). Application of goal programming approach on finding an optimal land allocation for five other field crops in Anuradhapura district. An International Journal Operations Research and Applications (ORAJ), $4(2)$.

IUCN (2015). Project Implementation Plan. IUCN programme on Restoring Traditional Cascading Tank Systems Technical Note \# 1. Colombo: IUCN, International Union for Conservation of Nature, Colombo, Sri Lanka \& Government of Sri Lanka. pp.34

IUCN (2016). Restoring Traditional Cascading Tank Systems: Achievements in the Kapiriggama Cascade. Colombo: IUCN, International Union for Conservation of Nature, Colombo, Sri Lanka \& Government of Sri Lanka.

Itakura, J. (1995). Water balance model for planning rehabilitation of a tank cascade irrigation system in Sri Lanka (No. 37). International Water Management Institute.

Jain, R., Kingsly, I., Chand, R., Raju, S.S., Srivastava, S.K., Kaur, A.P. and Singh, J. (2019). Methodology for region level optimum crop plan. International Journal of Information Technology. 11(4), 619-624.

Kanthilanka, H. (2020) Personal communication.

Marques, G.F., Lund, J.R. and Howitt, R.E. (2005). Modeling irrigated agricultural production and water use decisions under water supply uncertainty. Water Resources Research, 41(8). doi:10.1029/2005wr004048

Monaco, F., Sali, G., Ben Hassen, M., Facchi, A., Romani, M. and Valè, G. (2016). Water management options for rice cultivation in a temperate area: A multi-objective model to explore economic and water saving results. Water. 8(8), 336.

Nazer, D.W., Tilmant, A., Mimi, Z., Siebel, M.A., Van der Zaag, P. and Gijzen, H.J. (2011). Optimizing irrigation water use in the West Bank, Palestine (Retraction of vol 97, pg 339, 2010). Agricultural Water Management. 98(4), 732732.

Rajendran, M., Gunawardena, E.R.N. and Dayawansa, N.D.K. (2020). Runoff Prediction in an Ungauged Catchment of Upper Deduru Oya Basin, Sri Lanka: A Comparison of HEC-HMS and WEAP Models. International Journal of Progressive Sciences and Technologies, 18(2), 121-129.

Shreedhar, R., Hiremath, C.G. and Shetty, G.G. (2015). Optimization of cropping pattern using linear programming model for Markandeya command area. International Journal of Scientific and Engineering Research. 6(9), 1311-1325.

Singh, A. (2016). Optimal allocation of resources for increasing farm revenue under hydrological uncertainty. Water Resources Management, 30(7), 2569-2580.

Singh, A. (2017). Optimal allocation of water and land resources for maximizing the farm income and minimizing the irrigation-induced environmental problems. Stochastic Environmental Research and Risk Assessment, 31(5), 1147-1154.

Sirisena, D. N., Silva, A.G.S.D. and Wanninayake, W. M.N. (2016). Long Term Application of Organic Manure and Chemical Fertilizers on Rice Productivity and Fertility in Paddy Growing Soils in Kurunegala District. Annals of Sri Lanka Department of Agriculture, 18: 6-8. 
Sofi, N.A., Ahmed, A., Ahmad, M. and Bhat, B.A. (2015). Decision making in agriculture: A linear programming approach. International Journal of Modern Mathematical Sciences. 13(2), 160169.

Weerahewa, J. and Zubair, S.M.M. (1990). An empirical test of multiple objective vs single objective decision making in agricultural production. Tropical Agricultural Research. 2.

Withanachchi, S.S., Köpke, S., Withanachchi, C.R., Pathiranage, R. and Ploeger, A. (2014). Cross- scale Dynamics in dry zonal paddy cultivation in Mahaweli River Basin, Sri Lanka: An analysis of spatial and temporal climate change impacts in water resource management. Climate. 2(4), 329-354.

Zenis, F.M., Supian, S. and Lesmana, E. (2018). Optimization of land use of agricultural farms in Sumedang regency by using linear programming models. IOP Conference Series: Materials Science and Engineering (Vol. 332, No. 1, p. 012021). IOP Publishing. 


\section{SUPPLEMENTARY MATERIALS}

Supplementary Material - Table 1: LP tableau for Baseline Equilibrium

\begin{tabular}{|c|c|c|c|c|c|c|c|c|}
\hline & & \multicolumn{3}{|c|}{ Maha } & \multicolumn{3}{|c|}{ Yala } & \multirow[b]{2}{*}{$\begin{array}{c}\text { Resources } \\
\text { available }\end{array}$} \\
\hline & & $\begin{array}{c}\text { Rice } \\
\text { (4 month) }\end{array}$ & Maize & Vegetables & $\begin{array}{c}\text { Rice } \\
\text { (4 month) }\end{array}$ & Maize & Vegetables & \\
\hline $\begin{array}{l}\text { Objective function } \\
\text { coefficients }\end{array}$ & & 70,424 & 91,427 & 296,520 & 70,424 & 91,427 & 296,520 & n.a. \\
\hline \multirow{2}{*}{$\begin{array}{l}\text { Labour (man- } \\
\text { days/ha) }\end{array}$} & Hired labour & 15 & 15 & 84 & 15 & 15 & 84 & 2274 \\
\hline & Family labour & 32 & 101 & 126 & 32 & 101 & 126 & 4987 \\
\hline \multirow{12}{*}{ Water (ha-meter) } & Nov & 0.280 & 0.192 & 0.088 & & & & 27.75 \\
\hline & Dec & 0.512 & 0.372 & 0.192 & & & & 50.82 \\
\hline & Jan & 0.265 & 0.125 & 0.079 & & & & 26.15 \\
\hline & Feb & & & & & & & 0 \\
\hline & Mar & & & & & & & 0 \\
\hline & Apr & & & & 0.137 & 0.058 & 0.046 & 5.55 \\
\hline & Jun & & & & 0.512 & 0.372 & 0.192 & 20.72 \\
\hline & Jul & & & & 0.265 & 0.125 & 0.079 & 10.61 \\
\hline & Aug & & & & & & & 0 \\
\hline & Sep & & & & & & & 0 \\
\hline & Lowlands - Maha & 1 & 0 & 0 & & & & 97.23 \\
\hline & Highlands - Maha & 0 & 1 & 1 & & & & 18.21 \\
\hline \multirow{2}{*}{ Land (ha) } & Lowlands - Yala & & & & 1 & 0 & 0 & 97.23 \\
\hline & Highlands - Yala & & & & 0 & 1 & 1 & 18.21 \\
\hline
\end{tabular}


Supplementary Material - Table 2: Shadow prices of water constraints under each scenario(LKR/ha-meter)

\begin{tabular}{|c|c|c|c|c|c|c|c|c|c|}
\hline \multirow{2}{*}{ Climate Scenario } & \multirow{2}{*}{\multicolumn{2}{|c|}{ Simulation }} & \multicolumn{3}{|c|}{ Maha } & \multicolumn{4}{|c|}{ Yala } \\
\hline & & & October & December & January & April & May & June & July \\
\hline \multirow[t]{3}{*}{ Good year } & Baseline & & 0 & 23,616 & 0 & 0 & 30,977 & 0 & 22,668 \\
\hline & Short-aged rice & & 0 & 1,856 & 50,086 & 0 & 2,432 & 0 & 51,869 \\
\hline & Traditional rice & & 0 & 0 & 0 & 0 & 81,412 & 0 & 59,571 \\
\hline \multirow[t]{4}{*}{ Yala drought } & Baseline & & 0 & 49,048 & 0 & 869,855 & 0 & 0 & 0 \\
\hline & Desiltation & & 104,995 & 0 & 0 & 104,995 & 0 & 0 & 0 \\
\hline & Short-aged rice & & 0 & 1,889 & 50,896 & 20,722 & 41,436 & 0 & 0 \\
\hline & Traditional rice & & 0 & 87,192 & 0 & 813,648 & 0 & 0 & 0 \\
\hline \multirow[t]{5}{*}{ Maha drought } & Baseline & & $6,485,704$ & 0 & 0 & 0 & 0 & 137,529 & 0 \\
\hline & Desiltation & & 869,854 & 0 & 0 & 0 & 49,048 & 0 & 0 \\
\hline & Short-aged rice & & 65,060 & 0 & 53,726 & 0 & 34,715 & 10,264 & 0 \\
\hline & $\begin{array}{l}\text { Short-aged rice } \\
\text { desiltation }\end{array}$ & & 405,357 & 0 & 0 & 405,357 & 0 & 0 & 0 \\
\hline & Traditional rice & & $6,485,704$ & 0 & 0 & 0 & 0 & 178,543 & 0 \\
\hline \multirow[t]{5}{*}{ Year round Drought } & Baseline & & $6,485,704$ & 0 & 0 & $6,485,704$ & 0 & 0 & 0 \\
\hline & Desiltation & & $6,485,704$ & 0 & 0 & $6,485,704$ & 0 & 0 & 0 \\
\hline & Short-aged rice & & $6,048,178$ & 0 & 252,415 & $6,095,573$ & 201,795 & 0 & 0 \\
\hline & $\begin{array}{l}\text { Short-aged rice } \\
\text { desiltation }\end{array}$ & + & 405,357 & 0 & 0 & 405,357 & 0 & 0 & 0 \\
\hline & Traditional rice & & $6,485,704$ & 0 & 0 & $6,485,704$ & 0 & 0 & 0 \\
\hline
\end{tabular}


Supplementary Material - Table 3: Shadow prices of land (LKR/ha) and labour (LKR/man-day) under each scenario

\begin{tabular}{|c|c|c|c|c|c|c|c|}
\hline Climate Scenario & Simulation & $\begin{array}{c}\text { Lowland } \\
\text { Maha }\end{array}$ & $\begin{array}{c}\text { Lowland } \\
\text { Yala }\end{array}$ & $\begin{array}{l}\text { Upland } \\
\text { Maha }\end{array}$ & $\begin{array}{c}\text { Upland } \\
\text { Yala }\end{array}$ & $\begin{array}{l}\text { Family } \\
\text { labour }\end{array}$ & Hired labour \\
\hline \multirow[t]{6}{*}{ Good year } & Baseline & 2,604 & & & & 424 & 2,838 \\
\hline & Desiltation & & & & & 339 & 4,015 \\
\hline & Short-aged rice & 203 & & & & 448 & 2,806 \\
\hline & Short-aged rice + desiltation & & & & & 339 & 4,015 \\
\hline & Traditional rice & 6,847 & & & & 260 & 2,997 \\
\hline & Traditional rice + desiltation & & & & & 35 & 6,089 \\
\hline \multirow[t]{6}{*}{ Yala drought } & Baseline & & & 30,351 & & & 3,056 \\
\hline & Desiltation & & & & & 459 & 2,783 \\
\hline & Short-aged rice & & & & & 446 & 2,808 \\
\hline & Short -aged desiltation & & & & & 339 & 4,014 \\
\hline & Traditional rice & & & 14,695 & & & 3,155 \\
\hline & Traditional rice + Desiltation & & & & & 351 & 2,851 \\
\hline \multirow[t]{6}{*}{ Maha drought } & Baseline & & & & 270,110 & & \\
\hline & Desiltation & & & & 30,349 & & 3,056 \\
\hline & Short-aged rice & & & & & 404 & 2,862 \\
\hline & Short-aged rice+ desiltation & & & & & 339 & 4,015 \\
\hline & Traditional variety & & & & 262,235 & & \\
\hline & Traditional rice + desiltation & & & & 14,695 & & 3,155 \\
\hline Year-round drought & Short-aged rice+ desiltation & & & & & & 4,750 \\
\hline
\end{tabular}




\section{Supplementary Material - Box 1: Government interventions to restore VTCSs in Sri Lanka}

The government of Sri Lanka, in collaboration with various development agencies, has been investing to repair and rehabilitate minor irrigation tanks since its independence in 1948. Some of the key efforts include (i) The Village Irrigation Rehabilitation Project (VIRP), (ii) The Integrated Rural Development Project (IRDP), (iii) The NORAD funded programme in Hambantota (HIRDEP), (iv). NGO tank rehabilitation programmes; (v) The Freedom from Hunger Campaign (FFHC); and (vi) The Anuradhapura Dry Zone Agriculture Project (ADZAP) (IUCN, 2015). The more recent programmes initiated in the central dry zone of Sri Lanka include rehabilitation of 10,000 village tank schemes programme in 2004, the cascade development programme of the Mahaweli Authority of Sri Lanka launched 2004 which used partial desilting techniques to remove sediment in ten tanks, cascadebased small tank rehabilitation programme 2004-2009 and programme on restoration of natural habitats in a village tank ecosystem 2007 - 2008. In addition, the Food and Agriculture Organization (FAO) implemented several programmes to restore the ecological features of the VTCSs. Efforts have been made to tap emerging niche markets for non-traditional agricultural products such as organically produced native products (food, herbal medicine, etc.) in some of the above programmes. Attempts have been made to promote the use of traditional crop varieties through natural farming means as a reaction to observed increases in renal (kidney) ailments in the dry zone areas. In most of the recent programmes, partial desiltation has been promoted as a technology to rehabilitate tanks. The process of desiltation in this concept is to reduce tank water losses by manipulating the tank bed geometry through desiltation.

\section{Sources:}

http://www.fao.org/3/a-bp893e.pdf

http://www.fao.org/srilanka/news/detail-events/en/c/1118377/

https://www.iucn.org/sites/dev/files/content/documents/pip final tn 1_dec_232015 1.pdf

https://www.iucn.org/sites/dev/files/content/documents/a strategic approach to enhance the syst em efficiency of village tanks th 5 jan 2220 1.pdf 